dulgences or the vicious habits of your patients; which will enable you to resist the sacrifice of your convictions to the tyranny of dominant opinion, or the seductions of popularity ; which, keeping you conscious of your own infirmities and errors, will make you candid and generous to the infirmities and errors of your professional brethren; which will teach you "to admire without envy", and to suffer without bitterness; and which, lifting you above the highest region of human interests and passions, and showing you how human freedom, like a "swimmer shaping his course in the stream which carries him along", is but a limited activity in the hands of overruling power, will place you in filial relations to the Eternal Mind.

This is the spirit which you should strive to cultivate in yourselves, as one of the most precious results of the knowledge which you will acquire, and of the discipline which you will practise within these walls. This is the spirit which will redeem you from failure and be your sure support in every time of trouble. Wealth may fail, friends may fail, you yourselves may fail, but this spirit, living and fructifying in you, will never fail. In the hurry, the turmoil, and the conflicts of life ; in fears that might dismay, and amid calamities that might overwhelm, it will abide with you and it will fill your hearts with the peace which passeth understanding - the peace which the world cannot give.

\section{MEDICINE IN 1876:}

BEING

\section{AN INOUIRY INTO THE EFFECTS OF EXPERI- MENTAL RESEARCHES ON THE PRINCIPLES AND PRACTICE OF MEDICINE.*}

BY JOHN EDWARD MORGAN, M.D., M.A.OxON.,

Fellow of the Royal College of Physicians : Professor of Medicine in the Owens College, Manchester; Physician to the Manchester Royal Infirmary.

Gentlemen,-We are to-day commencing another session. Many whom I see before me are now entering upon the battle of life. Each one of you has chosen for himself his future career. Commercial pursuits and a business life have no attraction for you. You have resolved to devote your lives to one of the learned professions. But, though your choice has been made, I feel persuaded that, to many of you, the selection of a calling has been no easy matter. It is difficult, at the age of eighteen or nineteen, to decide on that sphere of usefulness which will prove most congenial in after life. In choosing a calling we are beset by difficulties. In selecting such a profession as that of medicine, each one has doubtless asked himself this important question : "Is the step I am taking a wise one? Is the profession with which I am associating myself a mere empirical art, founded on no generally accepted or trustworthy principles, or is its teaching based on a vast collection of well-established truths, the outgrowth of many independent but collateral sciences ?" I will endeavour to solve the doubts that have arisen in your minds. The question you have asked yourselves I will strive to answer for you. Does, then, medicine rest on such sure foundations that both we, who have long been engaged in its practice, and you, who are to-day commencing its study, can feel satisfied that the ground under our feet is really secure?

In considering this subject, I do not propose, even in a cursory manner, to follow the progress of medicine through successive ages. Such knowledge you may acquire in the pages of an encyclopæedia. If you study the history of the healing art, as taught by the Chaldæans, the Greeks, the Egyptians, the Romans, or by the priests of the middle ages (the great expositors of the laws of health and of disease in those days), you will find that, for upwards of three thousand years, every. thing connected with the principles and practice of medicine was dark and uncertain. Theories were propounded, and for a time accepted; but as they rested on no sound scientific basis they were soon forgotten, to be replaced by other theories equally erroneous, and, as guides to practice, equally misleading. Particular methods of treatment were pursued for a season, then fell intodisuse, frequently to be again revived at a later period. Nor could it be otherwise. So long as everything bearing on the structure and functions of the different organs and tissues of which

* Opening Address at the Owens College School of Medicine, October and, Session $1876-7$. our frames are composed was either veiled in obscurity, or very imperfectly understood, no sure progress could be made.

Among the ancient physicians the symptoms of disease were noted with extraordinary care. No more careful observer of clinical phenomena ever lived than Hippocrates. But, in the days of Hippocrates, the significance of the nerves and arteries was altogether falsely interpreted. No practical advance could be made in the science of medicine while the arteries were looked upon as air-containing tubes. Yet these views were held by many, even in the most enlightened days of ancient Greece. Such ignorance, however, was not destined to last. Slowly, it is true, but still sureiy, the mechanism and relations of the component parts of the body were severally mastered. The anatomist commenced the work. By his labours the ground was cleared for other investigators. His task has been a long and tedious one; but he has nobly accomplished what he set himself to perform. Indeed, so thoroughly has it been carried out, that I believe we may with truth assert that, in the domain of human anatomy, we appear now to have reached a vantage ground. During the last fifteen or twenty years, comparatively little has been added to our store of knowledge in this direction. Indeed, the coarser structures which enter into the composition of our frames seem almost thoroughly worked out. Hand and eye have apparently gone as far as it is possible for them to go. Every muscle, every nerve which the eye can discover, the dissecting blade has followed out until it becomes lost in the surrounding tissues. In the thorough knowledge of anatomy, which has been bequeathed to us by many devoted and trustworthy observers, we possess immense advantages over those who have preceded us. Indeed it is to this knowledge that we are indebted for the important advances effected in surgery, no less than in other departments of practical medicine.

Nor is it alone in human anatomy that we seem at the present day to have reached a secure resting place. In morbid anatomy, likewise, our progress has been no less sure. Here also the unaided eye has pushed its researches as far almost as is permitted by the nature of the inquiry. We are thoroughly familiar with diseased structures, with the granular kidney, the cirrhotic liver, the fatty heart, and the degenerative changes observed in the bloodvessels. Each and all are readily recognised, and, were we dependent on our unassisted senses, it is questionable whether in this direction our knowledge could be much more extended. But no such limitation is possible. Though science for a time baffles her votaries, she still loves to reward them. When the eye failed to see, and seemed to exclaim "thus far can I go, but no further", other sciences came to the rescue. Histology took up the search. When objects no longer produce sufficiently large images on the retina, the microscope is required for their examination. When nerves and arteries grow so small that they are altogether lost in the surrounding tissues, the microscope opens out to our bewildered vision boundless fields of research. Of all optical instruments, this is the most perfect and complete. Of late years, its application to medicine has been immensely extended. In the present day every student has his microscope, and is instructed in its use. Through the labours of histologists, many questions, till lately clouded in obscurity, have been satisfactorily worked out. Twenty-five years ago, little was known regarding the relation of the ultimate nerve-fibres to muscle ; little also concerning the mode of origin of nerve-fibres in nerve-centres ; little of the structure of the capillary vessels ; little about the minute anatomy of the lymphatic system; little regarding the minute structure of the muscle tubes. These questions have now all been investigated. Though the information acquired be not in all respects so definite and exact as it doubtless will become, yet much has been garnered in the storehouse of knowledge.

In other directions, also, medicine has been aided by the allied sciences. Chemistry has shed a vast flood of light on subjects which, until comparatively lately, were but little understood. The coagulation of fibrin, the forces which regulate the filtration and diffusion of fluids through membranes, the specific constituents of the various secretions, the chemical processes which occur in muscle, the processes also which regulate the digestion of our food, have all been worked out with the most elaborate care, and have all more or less directly contributed to the advancement of medicine. But though in these, and in many other ways, our stock of knowledge has been increased, there is one science to which we, as practitioners of the healing art, are more especially indebted. I need scarcely tell you that I refer to physiology.

Two hundred and fifty years ago, Harvey, in discovering the circulation of the blood-in demonstrating that the liquid flesh in our bodies passes from the heart by the arteries, and returns again to the heart by the veins-unveiled to our forefathers the most momentous discovery (in its bearing on medicine) that the world has yet seen. This discovery, so convincing when explained, so shrouded in obscurity before it was brought to light by the great magician, has proved the very 
foundation-stone, not alone of physiology, but of everything bearing on practical medicine. For the secrets it has opened out to us, we are, in a great measure, indebted to experiments on living animals. Nearly two hundred years later, Sir Charles Bell, also by experimental researches, taught us that the anterior roots of the spinal nerves are nerves of motion, and the posterior roots are nerves of sensation. It is difficult to over-estimate the value of these two great discoveriesthe one mapping out for us the devious wanderings of the blood, the other tracing the paths by which sensations are conveyed to the centres capable of receiving them, and those also by which the behests of the brain are transmitted to the muscles. Thus Bell did for the nervous system what Harvey had before achieved for the vascular. They expounded to us the principles of that great reign of law which governs the life and movements of the animal creation. These heroes of science were both Englishmen. We may well feel proud of our countrymen for the legacies of knowledge wherewith they have enriched us.

But if credit be due to Englishmen for laying the foundation of human physiology, it is to foreigners that we are peculiarly indebted for the goodly proportions of the superstructure. It is in the laboratories of the Continent that methods of exact research have been most assiduously cultivated. Consider for a moment what has been done by Claude Bernard, Brown-Séquard, and the distinguished band of German investigators, who have, of late years, directed to physiology that spirit of indomitable energy, that determination in overcoming difficulties which, in former days, they expended in the elucidation of history, of philology, and of the abstract sciences. Appreciating the importance of exhaustive research, many of these men have devoted to some fractional department of physiology the concentrated labour of a life-time. What these investigators have done, the student may learn from such works as Hermann's Physiology, admirably translated into the English language by my colleague Professor Gamgee; who, not content with giving a faithful rendering of the original, has simplified much that in the German version is less happily expressed. The perusal of this and similar works will convince the most sceptical that, if medicine is ever, in the true sense of the word, to assume the rank of an exact science, it is through the portals of physiology she must hope to enter on that proud position. Richly, indeed, have the labours of the last twenty or twenty-five years been rewarded. How extended is our knowledge regarding the innervation of the heart! We now know that there are nerves whose function it is to quicken the heart's action; and again, that there are other nerve-fibres which cause that organ to contract more slowly. Consider also how much experimental investigations have taught us concerning a distinct class of secretory nerves, the vaso-motor nerves, and the duality of the vaso-motor system. In some portions of the system, as we have now learnt, these nerves run in the spinal cord; in others, in sympathetic trunks. It has been discovered, not only that there is a common central organ for the vasomotor nerves, but where that organ is situated. The nerves also which regulate the respiratory movements, and the influence they severally exert, have been carefully studied. To the muscular system also much attention has been paid. The independence of muscular irritability has been satisfactorily proved, while the mechanism of muscular contraction is more thoroughly understood.

Nor are these the only triumphs achieved of late years by means of the experimental researches which have added lustre to the teachings of physiology. Pathology also has made important gains. On many of those morbid processes which characterise the course of disease, fresh light has been shed. When Cohnheim proved by ocular demonstration that, under certain conditions, the white corpuscles separate themselves from the current of the blood, and traverse the walls of the vessels within which they are enclosed, a new vein of research was opened out, rich in the ore it is destined to yield. The significance of such a discovery is only realised when its extended bearing is fully understood. Its import and value are but slowly appreciated. We now know that not alone the white corpuscles, but the red also, may insinuate themselves through the tubes which usually confine them; and, by their intrusion on parts not destined to receive them, upset the harmonious working of the economy. Since this comparatively simple fact was observed, we can comprehend at least some of the sources from which the cells, that accumulate so rapidly during the process of in flammation, are derived. We can understand also how septic irritants may be conveyed to distant parts of the system, and there produce their fatal results. There are, moreover, some grounds for believing, with Dr. Classen and other observers, that it is to cell-emigration, rather than to cell-division, that we must look for the origin and development of those malignant growths which are popularly recognised under the name of cancer.

So, again, when Villemin, in 1865 , produced tubercle artificially in animals previously healthy, he threw open to succeeding explorers end- less avenues of research. Indeed, the experimental results already obtained seem to show that secondary tuberculosis may have its origin simply in some inflammatory affection. But whether the infective substance in tubercle is elaborated within the body, or introduced from without, is a question which, though at present undecided, will doubtless ere long be definitely solved. When we reflect that one-fifth of the death-toll exacted of this country is levied by the tubercular class of disorders, we can appreciate the significance of investigations directly tending to set bounds to their ravages; and feel convinced that the practical bearing of such researches must prove of the very utmost moment to suffering humanity.

The important discoveries in physiolozy and in pathology to which I have called your attention have all, in a greater or less degree, resulted from experiments made on living animals; and are of the utmost possible value to the medical practitioner, and through him to the general public. They are valuable, not alone for their direct results, but for those also that indirectly flow from them. In many respects, they are rather to be looked upon as suggestive than exhaustive. The examination of the vital phenomena presented by the tissues, and the investigation of their properties, demand, as many of you are aware, the most delicately constructed instruments and the utmost precision and nicety in their use. It is, therefore, satisfactory to feel that these inquiries are at the present day exclusively entrusted to those who, by a laborious preparation, no less than by great natural aptitude, are specially qualified for the work. Nothing is done in a careless or haphazard manner but system and method regulate the minutest details of the laboratory. Still, however carefully these observations are conducted, we are forced to admit that some suffering is necessarily inflicted on the brute creation ; but in this country, at all events, as has been conclusively shown, our physiologists, in their treatment of animals, have proved themselves humane and tender-hearted men. There has been no useless waste of life, no wanton prolongation of pain. Wherever sensibility can be blunted, the methods specially adapted for securing this happy result are sedulously applied.

We must all regret that, in the pursuit of knowledge, any pain, however slight, should be inflicted even on the humblest animals. Still we daily see that, in the economy of nature, a vast amount of suffering is everywhere inflicted by the stronger upon the weaker. Were the brute creation endowed with the same tender sensibilities which prevail among civilised beings, the whole span of their lives would be haunted with a dread of coming evil, and a reign of terror would mar the happiness of every living creature. But, though'much suffering undoubtedly does exist, the beasts of the field enjoy for the most part a contented and happy existence. There is amongst them neither the anticipation of coming evil, nor the retrospect of that which is past. They live in the present, and reck not of the violent death in store for them. The dog chases the cat and would tear her to pieces ; but she baffles her pursuer, and contentedly purrs over her safety by the fireside. The cat, again, gladdened for years by the sweet melody of the bird, no sooner sees the unwary prisoner emerge from its cage, than she compasses its destruction. The bird, rescued from danger, celebrates its escape by renewed outbursts of song. We find, in fact, that among many animals the taking of life is a very law of existence. Even though hunger be satisfied, death is inflicted, often apparently from the mere instinct of destruction. Mankind, too, is responsible for much of the suffering to which the lower animals are subjected. Fishes, beasts, birds, and reptiles are not alone killed, but at times slowly tortured. The fish caught on the night-line must wait for morning to be relieved from his pain. The rabbit held by the unyielding spring of the steel trap, spends weary hours in mortal agony. The feathered fowls, whose plumage is ruffled by the unskilful sportsman, linger for days ere death releases them ; and even the worm, threaded alive upon the hook, may be conscious of his miserable fate. In these and numerous other ways, needless pain is wantonly inflicted for comparatively small results. Had a little more ingenuity been expended in the slaughter of these creatures their deaths might have been painless. Man, indeed, is a gainer by their destruction. In their death they minister to his convenience, to his pleasure, to his health; still, the sacrifice of the animal is not here followed by any important consequences. Individuals are benefited and amused; the mass of mankind are in no way bettered.

Such a remark, however, is in no way applicable to that infinitesimal quota of suffering inflicted by the physiologist in his quest after discoveries that may be useful, not alone to the human family, but to every species of animal. He trifles not with the existence of the meanest reptile, but he feels that can he but discover the laws which regulate the growth of tissue, the repair of injured structures, or the production of disease, the sacrifice of a single life may prolong the years and ease the miseries of countless thousands. 
I bave directed your attention to this subject because I think it important that you, who are to-day associating yourselves with the medical profession, should be able to join us with clean hands and a good conscience, satisfied that, as humane men, you can approve of the methods by which the science of medicine has been advanced. That those who have carried on these investigations have, as a rule, evinced sentiments of humanity towards the lower animals, it is impossible to deny. Many of them have felt reluctance in carrying on the most important researches, because they occasioned a certain amount of pain. But how have these disinterested labours been appreciated by those whose infirmities they were intended to relieve? How have the persons benefited by chloroform, and ether, and chloral, and nitrite of amyl rewarded the men who, in many cases, endangered their own lives, and in more than one instance actually perished themselves, that they might assuage the sufferings of others? Such persons greedily avail themselves of the balm that ministers to their pain, while they scruple not to vilify the hand that won their relief. In this free land, where freedom, alas, is too often abused, many people, well-meaning, doubtless, but fussy and self-opinionative, hesitate not to denounce in the severest manner the men to whom science is so deeply indebted. By banding together and making the question of vivisection a political watcliword, they succeeded in putting such pressure on the Government of this country, that a Royal Commission was appointed specially to investigate the "practice of subjecting live animals to experiments for scientific purposes". Among the members of that Commission were several distinguished statesmen, and at least one name well known to science. After a protracted in quiry into the whole question, these Commissioners came unanimously to the conclusion, "That it is impossible altogether to prevent the practice of making experiments upon living animals for the obtainment of knowledge applicable to the mitigation of human suffering or the prolongation of human life"; and, again, "the greatest mitigations of human suffering have been in part derived from such experiments". They further expressed the opinion, that "a general sentiment of humanity on this subject appears to pervade all classes in this country". If, then, it was apparent, even to men of no scientific attainments, that such experiments are of the greatest value ; if it was shown, moreover, that they are at the present time carried out in an humane and merciful manner, why was it deemed necessary to inflict on the great profession of medicine such an insult as that to which it was subjected by the provisions of the Bill introduced into the Upper House by the Secretary of State for the Colonies? Mankind had benefited by these researches; misery had been relieved, science advanced, no charge of wanton cruelty could be brought home to the experimenters; and yet, forsooth ! these men were to be dogged and baffled in their beneficent labours by the common guardians of public order as though they were cock-fighters or bull-baiters. The second reading of this Bill, modified somewhat, it is true, but still most objectionable in its enactments, was carried through the House of Cornmons on August 9th. The next day, the last of the session, the Cruelty to Animals Bill was hurried through Committee, and, on the I5th, received the Royal assent-as sorry a piece of legislation as has been turned out of the House of Commons for many years. Introduced, doubtless, for party purposes, it was altogether unworthy of a strong government.

You are aware that this question has excited a very general feeling of indignation in the medical profession. If any men have a prescriptive right to consider themselves the special guardians of our common humanity, those men are the physicians and surgeons of England. During the still hours of night, while the followers of other callings enjoy their well-earned repose, the hard worked disciples of Esculapius keep their weary watch by the sick man's pillow, and render him succour with no grudging hand. Their motto is "Work, not talk". They have no leisure for the seductive harangues of platform oratory.

I feel persuaded that many of our lawgivers must feel that their conduct in the matter of this Cruelty to Animals Bill has been, to use the mildest expression, somewhat inconsistent. As English gentlemen, they are generally familiar with the phases of cruelty inseparably associated with a sportsman's life. A large proportion of them, at stated periods of the year, indulge in the time-honoured custom of killing game. They hunt and they shoot; but, in a day's sport, every creature that is shot at is not necessarily killed. The wounded, likewise, claim our sympathies. Could the maimed survivoors of some lordly battue respond to the roll-call and compare experiences with the rabbit or the dog experimented upon by the physiologist, it is possible that the balance of suffering inflicted might rest with the man of the gun. Others of our senators, staunch patrons of the turf, who close the halls of St. Stephen's that their undivided attention may be given to the Derby, must be aware that the sharp edge of the spur, driven into the flank of the sorely pressed steed, occasions as keen a pang as is inflicted on the web of the frog by the needle of the physiologist.

In making these remarks, I am especially anxious that my opinions on this subject should not be misinterpreted. As a keen sportsman myself, I should be the last man to interfere with the recreation of others. But I do think, in reference to this matter, a certain amount of mawkish sentimentality appears to possess the public mind. The Commissioners who tested the whole subject of vivisection, found that at least one distinguished physiologist, though devoted to sport, abandoned the pastime from his conviction of its cruelty. So long as we find our experimenters actuated by such feelings as these, we may, with the most complete confidence, entrust to their keeping the lives of our dumb animals.

I have to!d you that, by experiments made on living creatures, medicine, viewed as a science, has been rendered much more exact. Has the practice of the healing art advanced in an equal ratio? Those who are acquainted with what has been done in the domain of therapeutics, must admit that here also great progress is everywhere apparent. I freely admit that the morbid processes undermining the health of our patients are oftentimes of so desperate a character that we are baffled in our efforts to cure their disorders. Still, thanks to modern discoveries, we can now treat them on rational principles. The strange vagaries (if I may be allowed to use the expression) in practice which characterise the history of medicine in past ages, will not be repeated in the days that are coming. We now know that there is a nerve whose special function it is to retard the heart's action; and we know, also, that certain remedies (belladonna, for example) exercise a direct influence on this nerve. Possessed of such knowledge, we can at all events treat some forms of exalted cardiac action in an intelligent manner. Again, we have learnt by experimental researches that nitrite of amyl influences the vaso-motor nerves, and relieves the tension of the small blood-vessels. By acting on this system of nerves in those frightful maladies angina pectoris and asthma, we unlock the spasm and relieve the sufferer from his distracting torments. The nature of epilepsy and diabetes, those widespread scourges of our kind, has of late been satisfactorily gauged, and the treatment of their manifestations is necessarily more hopeful. So, arain, the influence exerted by particular drugs on the specific secretions of some of the more important glands has proved a most valuable guide to our practice. We now know how to stimulate these organs, and we know also how their action may be restrained.

But there is no direction in which our progress as scientific physicians has been more remarkable than in the way we deal with the heightened temperature of the human body. In health, as most of you are aware, the temperature is almost constantly the same. When fever assails us, however, sundry processes which go on in the system tend to the production of heat. If the temperature rise only two or three degrees, the various organs no longer fulfil their functions in a normal manner. Sundry subjective symptoms, thirst and lassitude and headache, are all liable to supervene. When the rise in temperature is more considerable, not only are pulse and respiration greatly accelerated, but we observe also a marked alteration in the secretions, grave functional disturbances of the brain, and a tendency to divers local congestions. But the bodily heat, we will suppose, continues to increase until 105 deg., or even 106 deg. or 107 deg. are registered on the thermometric scale. With such a temperature, life cannot long be maintained. Many organs in the body rapidly undergo parenchymatous degeneration. Their cell-elements are changed, often completely destroyed. The heart participates in these morbid changes; it becomes soft, and is easily torn. Finally, the excessive action of the hot blood leads to cardiac paralysis and certain death. To such cases, in former days, no efficient assistance could be rendered. The very ablest physician was compelled to stand by with folded arms, powerless to save. We now know that, can we but succeed in bringing down the temperature, recovery is possible. How may this happy result be accomplished? Simply by immersing the sufferer in cold water whenever the blood-heat rises above a certain point. The clinical investigations of Bartels, Jürgensen, Liebermeister, and many others, have shown " that, in the majority of patients, thoroughly cold baths may be used without danger as often as may be necessary; that is, as often as the temperature in the interior of the body may again have risen beyond a certain limit". Great results can only be obtained by controlling the temperature of the patient both by day and night. From four to eight baths in the twenty-four hours have usually been required; but, in severe cases, as many as twelve may be necessary. By this method of treatment, the mortality from typhoid fever has been reduced in one hospital on the Continent from 25 to 7 per cent., and in another from 15 to 3 per cent. I am well aware that cold water has long been looked upon as a valuable remedy in a great variety of 
disorders. But, in former days, the mode of its application was more or less empirical; now its use is based upon the teachings of science. Pathology has shown us that the danger of fever consists in the deleterious influence of a high temperature on the tissues. Medical thermometry has taught us when the treatment should be applied, and when also it may be most appropriately repeated. Other remedies also enable us to contend successfully with that increase of temperature which is so symptomatic of fever, and, at the same time, so fraught with danger. Quinine has long been looked upon as one of the most valuable preparations contained in the Pharmacopaia. It is only of late, however, that we have mastered some of its more remarkable properties.

Twenty years ago, the man who administered quinine at the height of an attack of fever did not frame his prescriptions after the orthodox teaching of the day. We now know that, even in the most acute cases of fever, very large doses of this remedy may be administered with the happiest results, the temperature being at once sensibly lowered. Other preparations, such as alcohol, digitalis, and veratrium, act in a similar manner; they all lower the blood-heat.

The remarkable advance which distinguishes every department of medicine is conspicuously apparent in surgery. It is difficult at the present day to realise how miserable may be human existence without the timely succour of the chirurgical art. But turn for a moment to the classical writings of the ancient authors, where the joys and sorrows of daily life are pourtrayed with simple yet striking fidelity. Some of you, I doubt not, are familiar with the Philoctetes of Sophocles. Philoctetes, as the legend goes, while rashly treading upon consecrated ground, was bitten in the foot by a venomous snake. The wound festered, and so offensive became the sloughing sore, and so harrowing were the sufferer's cries of agony, that his very presence was loathed by his fellow-voyagers. By the advice of the wily Ulysses, he was landed while asleep on the desert isle of Lemnos, and there left alone in his misery. Here, for nine weary years, he was afflicted with excruciating torture, and made the very rocks and caves re-echo with his howls and lamentations :

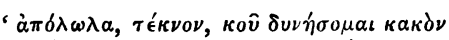

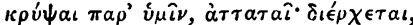

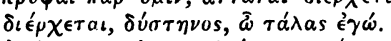

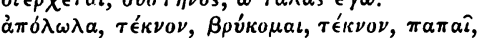

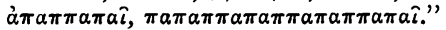

At times, indeed, exhausted by the bitterness of his woes, he sank into a death-like slumber, thus enjoying a brief respite from anguish.

The unbefriended condition of this poor outcast teaches us how terrible may be the consequences of even a trivial accident when no skilled hand is there to succour. The Greeks, we know, were no poltroons, no faint-hearted race of men. Philoctetes, too, as the armour-bearer of Hercules, was familiar with the stern realities of a warrior's life ; yet even he, by the intensity of his woes, was forced to indulge in the wildest manifestations of unrestrained grief. Had his birth but been postponed for three thousand years, how different had been his experience. Chloroform, disinfectants, and the elaborate appliances of modern surgery, would have taught him that even pain itself is amenable to science.

Having thus referred you to the past, let me now turn to the present. Many whom I see before me are more familiar than I am with the brilliant achievements that have of late years added lustre to surgery. You are well aware how valuable has been the discovery of the antiseptic method of treating wounds. For the introduction and working out of that mode of treatment we are indebted to an EnglishmanProfessor Lister. The reception accorded to our distinguished countryman by the teachers and students of medicine in many of the great cities of the Continent must have convinced the most sceptical how widely appreciated are the doctrines Mr. Lister has laboured to promulgate. You, who have been educated in this school, have enjoyed special opportunities of studying the practical application of this mode of treatment. In the Manchester Infirmary, antiseptic surgery has been carried out for the last seven years with scrupulous care, and with the utmost assiduity, by the able professor of surgery in this college. Mr. Lund, with the single exception of Mr. Lister, has bestowed more time and thought on the practical application of this discovery than any man living. You are yourselves, therefore, in a position duly to appreciate its effects.

In Germany also, surgery, like the other departments of medicine, has chronicled some remarkable results. In I\$69, Dr. Simon determined upon removing the left kidney in a case of ovariotomy, in which one of the ureters had been unavoidably severed. The operation was a daring one, and well might he pause ere he grappled with his task. Before proceeding to execute his purpose, he felt it his duty to perform a considerable number of experiments upon animals, partly with a view of discovering how far the remaining kidney would take upon itself a double function, partly to measure the risk to which he was subjecting his patient. As the result of these experiments proved satisfactory, he considered himself warranted in venturing upon the hazardous operation. His perseverance, his skill, and his courage were rewarded by the most complete success. He had the satisfaction of seeing the afflicted sufferer under his care permanently and thoroughly cured. Some dogs, indeed, had unfortunately been sacrificed, but an useful life had been rescued from protracted suffering and from a miserable death. Only last year, an accident similar to that which befell Dr. Simon's patient occurred in the practice of Professor von Nussbaum of Munich. Though familiar with the investigations of Simon, Nussbaum felt satisfied that, in the reduced state of his patient, so severe a shock as extirpation of the kidney would in all probability prove fatal. He, therefore, conceived the idea of affording relief by the formation of an artificial ureter. The reasons that decided him to adopt this procedure, the manner in which he effectually carried it into practice, and the difficulties he overcame, you will find fully detailed in the medical journals. This operation was performed on November roth, I875, and was crowned with the most complete success. It marks a distinct era in the history of surgery.

But there is another direction in which the art of the surgeon has of late years proved powerful to save. In 1873, Professor Billroth of Vienna, in a case of malignant disease, ventured to remove the whole of the larynx. The man whose life he thus prolonged was able by an ingenious apparatus both to speak and to swallow. In this case, Billroth was led to undertake the operation by the success which attended at least some of Dr. Czerny's experiments on dogs. Had Czerny not demonstrated that the life of an animal may be maintained even though the whole of the larynx be extirpated, Billroth would not have felt himself justified in undertaking so critical a venture. Hence we see that, by experiments on animals, at least two most important operations have quite recently been introduced into the practice of surgery. Those who know how intensely painful are many of the affections of the kidney and larynx, and who know also by bitter experience how frequent are the occasions on which these organs are attacked by incurable disease, will admit that the knowledge that they may be completely extirpated, and success attend the operation, must exercise a most important influence on the development of modern surgery. Will any surgeon, after this, be bold enough to assert that surgery has not been advanced by experimental researches?

In the foregoing remarks, I have endeavoured to show that, in every department of medicine, we may observe unmistakable signs of activity and progress. In entering the medical profession at the present day, you enjoy opportunities denied to the men of a former generation. Various instruments and appliances render the diagnosis of disease very much more easy and, at the same time, far more exact. In the sphygmograph, in the laryngoscope, in the ophthalmoscope, and in the clinical thermometer, you possess instruments which can assist you in mastering many difficult medical problems. The sphygmograph measures for you with far more accuracy than the most practised finger the force of the heart and the tension of the arteries. It tells you, therefore, in reading you cannot mistake, when sinking nature may be resuscitated by the needed stimulant. The laryngoscope enables you to explore the hidden recesses of the larynx and windpipe. It discloses to you the nature of the disorder, the seat of the disorder, and the spot to which your remedy may advantageously be applied. The ophthalmoscope also, if you but familiarise yourselves with its use, will unravel for you many complicated skeins in the phenomena of disease. It will reveal to you those remarkable changes in the optic nerve which throw so much light upon the pathology of nervous affections. It will tell you when morbid growths are encroaching on the brain, and even help you in localising their site. By its aid, you may discern the degenerative changes which assail the retina, and thereby gauge the ravages of disease in distant parts of the system that are concealed from your view. In the thermometer also you possess an instrument which will afford to you the most valuable and exact information. In many disorders, typhoid fever for example, the tracings of the thermometer not only record certain morbid changes, but actually define the very nature of the malady.

You may, then, feel assured that the profession you have chosen is one to which the best energies of your lives can profitably be devoted. Master conscientiously the precepts of medicine, and labour to carry those precepts with you into action, then, indeed, the allotted clays of each one of you will be usefully spent. You will thus find yourselves prepared for any emergency which may hereafter beset you, and will, to a greater extent than the members of any other calling, alleviate the sufferings of your fellow-men. 
I have told you that, in proportion as you master the principles and practice of your profession, you will be competent to distinguish every form of disease ; and you will be able to treat the ailments of humanity on rational principles. In former times, nothing more was required at your hands. In our day, however, modern society demands of you more extended attainments. You are not only expected to recognise illnesses, and to treat every individual case after the most approved fashion, but it is also your special mission to cure the outbreaks of epidemic disease. The members of our profession are everywhere looked upon as the trusted exponents of the laws of health. Many of you must prepare to serve your fellow-countrymen hereafter as officers of public health. Surely there is no way in which a well-educated and intelligent man can be more usefully engaged than in discharging the duties of this responsible office. For, in spite of our boasted education and the increased facilities for acquiring information enjoyed by us in this latter part of the nineteenth century, it is lamentable to observe how gross is the ignorance of the masses regarding all sanitary questions. Hence it is from you that guidance will be sought. Believe me, there are at our door many social and sanitary questions which will, at no distant day, inevitably demand attention. These questions must be solved, and in their solution you will play a prominent part.

Remember that, as a nation, we are every year separating ourselves more and more from a residence in the country and from rural pursuits, and are congregating together in the large towns. Hence our mode of life is constantly becoming more artificial, and, at the same time, more unnatural. In such a state of society, the tendency to disease is immensely increased, and the difficulty of coping with its inroads proportionately heightened. Alcohol, syphilis, and vitiated air are the breeders and propagators of constitutional maladies; while overcrowding and ignorance are, in a great measure, responsible for the so-called infectious diseases. Still, these latter disorders can all, in a greater or less degree, be prevented. By an efficient system of vaccination, small-pox, the most repulsive of them all, may well nigh be blotted out of the register of deaths. The ravages of scarlet fever, diphtheria, and kindred varieties of sickness, may be much reduced by timely and strict isolation; while cholera and typhoid fever may be circumscribed and stamped out by the thorough disinfection of the excreta. But if such results are to be achieved, diseases must be registered as well as deaths. For the prevention of contagious affections, death-registers are of little value; the information they give comes too late. When the epidemic is well set, when its roots and fibres have spread in divers directions, we may study its growth and progress in the bills of mortality; but, if we would deal with it effectually, we must crush the venom in isolated cases. Here only are we masters of the situation.

The Manchester and Salford Sanitary Association have well shown how such a work may be practically accomplished. To the reports of that society the public are indebted for much valuable information bearing on this subject. But such a system of disease-registration must be compulsory, and extend over the length and breadth of the land.

There are other diseases also which, if not altogether preventable, are in the present day better understood. We now know that consumption is peculiarly prevalent in certain districts and localities in this country; while in other places again heart disease, rheumatism, and cancer more especially flourish. These localities have of late been carefully mapped out, and their distinctive peculiarities studied and analysed. The differences thus noted are not attributable to blind chance ; but depend on laws which, in part at least, have been determined. The aspect, the geological conformation of the land, the subsoil water, the altitude; the hydrometric state of the atmosphere, the prevailing winds, all exert an influence, and what that influence is we are now beginning to understand. The bearing of these discoveries on public health must prove very important. When, for example, certain families manifest a marked proclivity to such affections as consumption, cancer, or heartdisease, we ought, wherever practicable, to counsel removal to districts where these diseases but seldom occur. Thus we may reasonably hope, in course of time, to eradicate that hereditary predisposition to the malady which is so potent a factor in its propagation.

There is another subject bearing on hygiene which especially demands your study and attention. If human beings are to enjoy health and live profitabie lives, they must be supplied with a breathable atmosphere. Nearly two thousand years ago, Virgil told us in his Georgics that, if vines are to flourish, they must be planted in straight drawn lines. Each tree would thus obtain an equal allowance of soil and of air. Similar rules should be followed in the construction of towns. Man cannot thrive without his due allowance of air. We are assured, indeed, that eighteen hundred cubic feet of air are amply sufficient for the sick poor in our large hospitals; though, it is needless to add, much depends on the quality of the atmosphere in which the building stands. We are not told, however, what number of persons may, with safety to health, be packed away on every acre of land in our large towns. Some sanitarians believe they have solved this problem by storing together whole hecatombs of beings in dwellings six and seven storeys in height. In this way, it is said that twelve hundred, or even sixteen hundred, persons may enjoy a healthy existence on a single acre. Still, we may well ask ourselves : Do not such human warehouses encroach on the vested rights of their neighbours? Do they not consume more light and more air than the area they occupy entitles them to use? Are the light and the air in the more lowly dwellings surrounding them in as wholesome a state as before their erection? These are questions which require to be solved. We can readily believe that isolated buildings of such colossal height may, if scattered over a large city, prove sufficiently healthy ; but we can hardly conceive that a populous town could safely be constructed after this model. At all events, one hundred thousand persons could scarcely be domiciled on eighty acres of land. Still, much would depend on situation; much, moreover, on the density of the population in the neighbouring district. Towns surrounded by the open country may be more thickly peopled than those encircled by other cities. For the reasons I have urged, we can readily understand that, though at one time the central portions of many of our large towns were airy and healthy, they are now barely inhabitable. Streets, fairly wide for a population of five or six thousand persons, are mere alleys in a city peopled by two or three hundred thousand souls. Yet, these unsavoury quarters of our towns are permitted to remain, and to serve as the breeding grounds and nurseries of epidemic disease. Should we not, then, impress upon those who are responsible for the public health, that the older parts of our great towns must be razed to the ground, and rebuilt on sounder principles, if wholesome habitations are to be secured for the masses? Moreover, regulations relating to the height and width of our streets should be far more stringent than they are at present, width being in all cases directly proportioned to height.

The whole question of the pollution of the atmosphere requires to be vigorously dealt with by those in authority. More consideration must be directed to the chemical constitution of the air we breathe. Air, taken from different quarters of our crowded cities, like the water sup plied by the London water companies, should be frequently tested, and the results published. In this manner we might hope to measure the influence exerted on life by the various noxious ingredients with which it is impregnated. Chemical tests, however, are not sufficient alone for our purpose. Information likely to prove useful might, I believe, be obtained from plants. Trees, as we know, utilise the products of the animal body. They reduce the water, the ammoniacal salts, and the carbonic acid; rearranging their radicals, they store them up in their own tissues, while they give back to the air the greater portion of the oxygen. From the air the animal obtains its much needed supply. Hence, as we see, plants and animals are mutually dependent the one on the other. In our crowded cities, however, nature is too often thwarted in endeavouring to carry out her immutable laws. Trees and shrubs are looked upon as intruders, and are not permitted to grow. Hence the air, after being breathed by the animal, is not reduced by the plant. Respired again and again by densely packed masses of humar beings, and contaminated by other impurities, it becomes so thoroughly vitiated as, in many instances, to prove actually poisonous to almost every kind of vegetation. In the influence exerted by a tainted atmosphere on different varieties of plants, we possess, I believe, a gauge of the comparative salubrity of different localities--a gauge of which we might avail ourselves as a test of aerial contamination. Whenever we find, for example, that trees will not thrive, there, we may be very certain, it is impossible for human beings either to enjoy a healthy state of existence. Different impurities in the atmosphere act upon different kinds of plants ; hence small enclosures, containing trees and shrubs of an accepted standard of hardihood, planted in a soil of uniform composition, would, I feel persuaded, demonstrate at least some of the effects of a polluted atmosphere both upon animals and man-effects which no chemical tests, however delicate, could ever analyse. Not only the air would thus be tested, but the influence of light and of the sun's rays on development and growth would be strikingly indicated.

Residence in the town, as we all know, never can prove so conducive to health as when life is passed in the green fields of the open country. Still, even in a city, life may be more prolonged and existence more tolerable than it is at the present day among the generality of the population. Some interesting statistics, regarding the physical condition of the Jews, have lately been published by Dr. Hough and others. From these records, it appears that this remarkable nation, though almost entirely a town-dwelling race (for only two per cent. of the Jews follow agricultural pursuits), are very much more healthy than the average populations among whom they are settled, both on the Continent and in this country. In London, for example, the average dura- 
tion of the life of the Jew is forty-nine years ; of the Christian it is only thirty-seven years. Hence it appears that the life prospects of the Jew are nearly twenty-five per cent. more favourable than those of his Christian fellow-townsman. The vitality so characteristic of the descendants of Abraham can be traced to very simple causes. In their sobriety and cleanliness, both domestic and personal ; in the care they bestow on themselves and on all dependent upon them ; and in their forethought and prudence, we find the true explanation of their remarkable longevity and superior resistance to disease. These statistics concerning the Hebrews are fraught with instruction to every Gentile nation among whom they dwell. The Christian labours for the conversion of the Jew. May not the Jew, in his turn, well desire the reformation of the Christian?

I will assume, then, that you are well content with the promises held out to you by your profession. Are you equally satisfied with the school you have selected? Many young men are impressed with the notion that every department of medicine may be most profitably studied in the great metropolis. Are there valid grounds for this opinion? Where, I would ask; do you find laboratories and appliances better calculated to aid you in your work than those contained in these buildings? What London students can boast of a library equal to that which is accessible to you ? Here, too, the most important chairs connected with medical education are held by professors whose undivided energies are devoted to your instruction. The best portion of their day is not set apart to the exacting requirements of private practice, but is bestowed on you. The "scarcity of subjects" also, which often retards the London student in his course of anatomy, is never experienced by you. Moreover, the manner in which you have acquitted yourselves in the various examinations for which you have competed, plainly testifies that the young practitioner educated in this College can challenge conclusions with the youth trained in any school in the country.

Nor need you look alone to the present-the future also is full of hope. There are good grounds for expecting that, before many years are past, this College will obtain its charter, and thus be raised to the more exalted rank of a northern university. You are aware that this question has of late been mooted in the public press. Many weighty organs of public opinion have treated the project with-a considerable degree of favour, while distinguished men of science have extended to the scheme their hearty approval. Whenever this change does come, as come it assuredly will, the medical faculty of our future university must be of paramount importance. In no country in Europe has the medical profession been so persistently slighted by the national universities as in England. Moreover, these learned societies, though doubtless well fitted for abstract subjects of study, are altogether unadapted for such a calling as medicine. In comparatively small towns, like Oxford and Cambridge, practical surgery and clinical medicine never can be successfully cultivated. The scattered population of a midland county, engaged in agricultural pursuits, supplies no extended scope for the surgeon's art. The University of London, as a degree-conferring Corporation, has doubtless, by the varied range of its examinations, stimulated many in the pursuit of knowledge. But the whole London system is more analogous to the Oxford and Cambridge Middle Class Examinations than in harmony with the accepted signification of the word " university". In the one case, a degree is conferred on the successful competitor; in the other, a certificate. But neither the recipient of the degree, nor he on whom the certificate is bestowed, derives his education from the university which rewards him. In a new university such an anomaly would never be repeated. No university is worthy of the name which, while defining its own curriculum, does not also provide an adequate staff of able professors, complete courses of instruction in the various faculties, and ample facilities for the prosecution of original research.

An university in the North of England would prove a great boon to many of you. Residing as you do within easy reach of Manchester, the severance of home ties and home associations would not be required for the suecessful prosecution of your university course. Your period of instruction would thus be prolonged, and, at the same time, rendered very much more complete. You would then be enabled to affix to your studies that coping stone which many of you now find it impossible to obtain. I have lectured in this school for the last fourteen years; during that time, I have enjoyed ample opportunities of estimating the industry and intelligence of the students whom it has been my privilege to address. My experience, therefore, is considerable ; and that ex perience teaches me that many of our ablest and most diligent young men are unable to obtain university degrees. Students who have gained prizes, and distinguished themselves at the competitive examinations, have expressed their regret at being prevented, by want of means, from pursuing their studies for an additional year in Scotland or in Ireland; for, remember, that nine-tenths of the medical degrees held in this coun- try have been obtained beyond the Tweed or on the other side of St. George's Channel. Had the relatives of such meritorious students resided within easy access of an university, their case would have been widely different. At the present time, young men without means are compelled to limit their aspirations to the membership of the College of Surgeons or to the licence of the Apothecaries' Hall. Yet, a degree does tell in after life, not only in the competition for public appointments, but in the less ambitious struggle of every day work. It certainly does seem a crying injustice that the fortunate possessor of one of these easily obtained degrees should, in later years, be preferred to his less wealthy, though often more talented, fellow-student. This injustice can be remedied only by the establishment of one or more universities in England, where the course of study shall be practical and thorough ; and where degrees shall be conferred upon those only who have earnestly qualified themselves to deserve them.

History teaches us that the nations which attain greatness are those that wisely avail themselves of their opportunities. Individuals also, if they would leave their mark behind them, must be on the alert to profit by the occasion. What is true of nations, and what is true also of men, is equally applicable to cities and to towns; they likewise have their day, when, if only they appreciate the significance of passing events, they grow prosperous and renowned. The enterprising among their citizens amass wealth; the studious and literary cultivate their taste for learning and for the arts ; while the poor are cared for in their seasons of sickness. The town in which this College stands-this city of Manchester-has, on the whole, been alive to its opportunities. It has grown rich and populous. Its Exchange is the largest in the whole world. Manchester is the acknowledged commercial nucleus not alone of the five hundred thousand persons who dwell immediately around its City Hall, but of four or five millions of the most industrious and most enterprising inhabitants of these islands. In former days, the political agitation which had so important a bearing on the destinies of this country originated in this town, and from here radiated to every village in the land. At the present time, political agitation is at a discount; politicians search, and search in vain, for a party rallying cry. But, if politics are lulled in slumber, social changes and domestic reforms are urgently needed. Above all, facilities for the acquisition of knowledge-in a word, a higher system of educationmust be provided for the great middle class of this country, who form the very backbone on which the whole fabric of modern society is supported. It is to the advancement of such an enlightened system of education that Manchester should now devote her energies and a portion of her wealth. As she has been the political centre around which, in former times, the great towns of the north of England rallied, and on which they rested, as she is now the commercial centre, so let her for the future aspire to become the intellectual centre. If she have these aspirations, and would fain desire to press onward in the paths of mental activity, let her be mindful that she has in this College a secure trysting-ground. Here the arts and sciences have taken root; here they have flourished for a quarter of a century; and here, if fostered and encouraged, they will attain to still more goodly proportions. If these sentiments be the sentiments of the people of Manchester, let us all endeavour, each according to his capacity and means, to promote the interests and extend the influence of the Owens College. The corner-stone of our future University is already laid. Let our motto, as fellow-citizens, be, "Union is strength". Let us remember henceforward that every stone added to the superstructure will hasten the proud day when the name of "Owens College" shall be merged in the yet nobler title of "The University of Manchester".

\section{THE PHOSPHORUS PILLS OF THE BRITISH PHARMACOPCEIA.}

By G. OW EN REES, M.D., F.R.S., Consulting Physician to Guy's Hospital.

THERE has lately been much discussion on the best method of compounding pills with phosphorus, and, among other plans, there is one proposed from the laboratory of Messrs. Savory and Moore, in a communication made to the Pharmaceutical Fournal. It is there stated, that the phosphorus pills of the British Pharmacopaia are apt to become sufficiently hard to escape solution during passage through the alimentary canal. The above fact was observed by me in the case of a gentleman who had my prescription dispensed by Messrs. Savory and Co., and who brought me the pills, retrieved from his stools, quite round, hard, and unaltered. I had previously used phosphorus pills made at Messrs. Savory's establishment by a process which produced an easy soluble pill, and had done so with great advantage in 